Research, part of a Special Feature on Landscape Scenarios and Multifunctionality - Making Land Use Assessment Operational

\title{
Pimp Your Landscape - a Generic Approach for Integrating Regional Stakeholder Needs into Land Use Planning
}

\author{
Christine Fürst $^{1}, \underline{\text { Hannes König }}^{2}, \underline{\text { Katrin Pietzsch }}^{3}, \underline{\text { Hans-Peter Ende }}^{2}$, and Franz Makeschin $^{1}$
}

\begin{abstract}
This article introduces Pimp your landscape, a tool that was developed for evaluating the effects of changes in land use patterns. The main application field is to support interactions and communication among actors in spatial planning. With this tool, different land use pattern alternatives can be visualized in a short time, and their impact on land use services can be evaluated immediately. Also, spatial training and environmental education with regard to sustainable land use management can be supported. The tool was developed in an iterative process, in close cooperation and over intensive exchanges with end-users. A resulting feature is the provision of two different modi oriented on the professional background and skills of the users. The biggest advantage of Pimp your landscape is the simple entry and handling. However, the system also offers the possibility to go in-depth and work with complex rule sets. The presented paper introduces the development background and development process of Pimp your landscape and describes the tool's resulting concept and actual usage. Finally, possible constraints of the use of the system and potential workarounds are discussed.
\end{abstract}

Key Words: Evaluation of land use pattern changes; generic approach; land use management support; rule setting options; spatial planning; user requirements analysis; visualization of land use pattern changes

\section{INTRODUCTION}

The status and functioning of landscapes are affected by political, economic, and demographic frame conditions (Schneeberger et al. 2007). New or modified environmental challenges are occurring due to worldwide climate trends, changing economies, and increasing societal needs as in, for example, Eastern Europe or the BRICs. BRICs is an acronym that refers to the fast-growing developing economies of Brazil, Russia, India, and China (Wilson and Purushothaman 2003). Furthermore, single land use types at the landscape level, such as forest ecosystems, are often characterized by a severe disturbance of their natural dynamics and by the fast development towards a new balance that likely has low stability and resilience (Dorren et al. 2004, Wilby et al. 2006). This dynamic development affects the fulfillment of socially requested functions, goods, and services, and must be considered in landscape planning (Bengtsson et al. 2000, Jessel and Jacobs 2005). In European landscapes, competing planning targets from directives such as Natura 2000 (including Species Protection Directive 79/409/EWG and Habitat Protection Directive 92/43/EWG), the European Union (EU) Water Framework Directive (2000/60/ EG), the EU Drinking Water Directive (98/83/EG), Environmental Pollution/IPCC Directive (96/61/ EG), NitrateDirective (91/676/EWG), Waste Water Directive (91/271/EWG), and the Soil Protection Strategy form additional sources of conflicts, especially when the prioritization of respective functions and services is demanded (e.g., Parker et al. 2008). Most of the resulting environmental or land management-related problems can be characterized by generalizable processes and temporal-spatial patterns (With and King 1997, Rounsevell et al. 2006b, Schmit et al. 2006, Gardner and Urban 2007). Differing regional and trans- 
regional patterns are resulting from the local, regional, and national differences in the socioeconomic targets of landowners and land users with regard to ecosystem protection and resource production.

A need to design multifunctional landscapes can be identified. Multifunctional landscapes ensure, for example, flood prevention and an appropriate drinking water supply, provide space for natural biodiversity and infrastructural development, and enable protection and production targets to be met at the same time (Haigh et al. 2004, Rounsevell et al. 2006a, Wilby et al. 2006). In terms of multifunctional land use, Wiggering et al. (2003) stress three points that are relevant for successful rural planning: (a) a demand- and goal-oriented identification of land use services, (b) a participative character of negotiations over possible land use combinations involving all relevant groups, including the scientific community, and (c) an iterative character of the decision-making process, which enables uncertainties to be tolerated on the one hand and adaptation to emerging information and knowledge on the other.

As a result, contemporary land use management requires dealing not only with complex questions but also with various needs of different actors or actor groups involved in the planning process (Letcher and Giupponi 2005, Niemelä et al. 2005, Dragosits et al. 2006, Kallioras et al. 2006). Therefore, there is a demand for instruments that are able to deal with challenges such as the fragmentation of information and missing data communication standards, and that also allow for complex knowledge and experience management (Wiggering et al. 2006, Mander et al. 2007, Van Delden et al. 2007). The concept of land use functions (LUFs) as developed in the EU funded Integrated Project SENSOR (Helming et al. 2008) considers such complex demands. The LUF framework focuses on functions, goods, and services that are provided by different land use types and that address the most relevant economic, environmental, and societal issues of a region in an integrative way. The LUF framework can be used for sustainability impact assessment at the regional level in an integrated and balanced way (König et al. 2010, Uthes et al. in press). The LUFs framework makes it possible for policy makers, scientists, and stakeholders to identify functions, which are reduced or enhanced under various scenarios of land use change, and to explore the trade-offs between them (Pérez-Soba et al. 2008, Schößer et al. 2009). The LUFs framework can be adapted and modified for visualizing and communicating possible impacts of land use changes to the multifunctionality of regional landscapes.

Approaches to developing environmental decision support systems or to combining multi-criteria analysis with modeling and simulation tend to integrate a broad information base and increase user-friendliness by sophisticated participatory approaches (Walker 2002, Mendoza and Prabhu 2005, Matthies et al. 2007). However, Uran and Jansen (2003) point out that there is a risk that the use of such systems is too complicated for a nonprofessional end-user, and that their application area is thus restricted to scientific purposes and professional users.

With these considerations taken into account, the software Pimp your landscape was developed in the frame of the INTERREG-III-a project IT-REG-EU (Integrated Trans-Regional Land use DecisionSupport in the Euro Region Neisse). The software was conceived as an online platform for visualizing and communicating complex interdependencies between land use pattern changes and land use services. The tool supports the participatory development of regional land use change scenarios by strengthening the integration of regional stakeholder needs in land use planning conflicts between forestry, water management, nature protection, and tourism (Fürst et al. 2008, 2009).

The objective of Pimp your landscape was to use a generic approach to simulate interactions and processes at the landscape level, and to translate them into rule systems, which can easily be adapted to variable regions and application cases (e.g., Holzkämper and Seppelt 2007). The name Pimp your landscape was chosen to intrigue end-users and to motivate them to test the tool. This paper introduces the methodological background and development process of Pimp your landscape, and describes the resulting concept and usage of the tool. Finally, possible constraints and how to deal with them are discussed. 


\section{METHODOLOGICAL BACKGROUND AND DEVELOPMENT PROCESS OF PIMP YOUR LANDSCAPE}

\section{Development background, user requirements analysis, and development process}

The regional development background of Pimp your landscape was characterized by border-crossing land use management and planning conflicts, which were studied as a test in the Euro Region Neisse. This region is situated in the border area between the Czech Republic, Germany, and Poland. Multiple stakeholder groups from forestry, water management, nature protection, and tourism are forced to cooperate for the realization of EU directives such as Natura 2000 and the EU Water Framework Directive. However, these groups also compete by addressing the same areas for different land use targets. Thematically oriented expert groups (EUREX working groups) in traffic, economy, tourism, water, forestry, crisis management, health, history, statistics, and education form the most important platform for exchange and discussion. Representatives of these working groups were consulted for the conception and development of Pimp your landscape.

The development process of Pimp your landscape was conceived as an iterative approach. Figure 1 shows the different development steps, including the applied methods, the number of involved endusers, and experts and the outcome for each subsequent step. At the beginning of the development process, 47 experts from the Czech Republic, Germany, and Poland were contacted based on recommendation of the common office of the three-country council of Euro Region Neisse. The recommended experts represented the most important stakeholder organizations in regional resource management and regional planning, and were expected to contribute their experience to the conception of the intended software. Fifteen experts did not have enough time to contribute, but 32 experts confirmed their participation. The confirmed participants came from forestry $(47 \%)$, nature protection $(33 \%)$, water management $(10 \%)$, and regional planning, including tourism (10\%). Twenty-one experts who were involved in the first step also participated in the live test. Additional test persons were involved in the second test run based on recommendation of the original participants. Only the persons in step IV (the application phase) were totally different, as the system was tested by them in the context of follow-up activities. These follow-up activities are not described in detail because they did not influence the concepts and results presented here.

The software conception began with a Delphi studybased user requirements analysis on how to design an optimal management tool (Dalkey and Helmer 1963, Turoff and Linstone 1975, Cooke 1991, Scholles 2001). In contrast to opinion polls, which use a random choice of participants and lack opinion feedback, the Delphi method is thought to obtain consensus among individuals who have special knowledge of an issue of interest (EVALSED 2003, Schmidt-Thomé 2005). Van Paassen et al. (2007) use the approach to develop computer models that facilitate the capability of learning about sustainable land use in rice-cultivating regions. White et al. (2004) developed an empirically based area-type model with the assistance of the Delphi method. Regarding the regional frame conditions under which Pimp your landscape was developed, the method was considered appropriate to address the experts in the EUREX working groups. A further advantage is the anonymity of Delphi participants, which allows them to interact, rethink, and compare their thoughts in a "non-threatening forum" without being influenced by each other's opinion (Miller 1993).

In the first round of the Delphi study, the following questions were posed (in each participant's respective national language):

(A1) What kind of information sources are you generally using to prepare interdisciplinary planning decisions?

(B1) Which tools are you using to visualize the planning process and to support your decision?

(C1) What do you think an optimal support system should look like for it to prepare the necessary information and support you as a decision maker?

For each question, a set of pre-selected alternatives was offered (Table 1). The participants were asked to evaluate the alternatives on a scale from 1 (= always/most desirable) to $6(=$ never $/$ most undesirable). Further alternatives could be proposed by the participants and were ranked on the scale from 1 to 6 . In round 2 of the Delphi study, only question $(\mathrm{C} 1)$ was repeated. 
Fig. 1. Development process of Pimp your landscape. Most working steps overlapped to ensure an intensive feedback between tests and technical development.

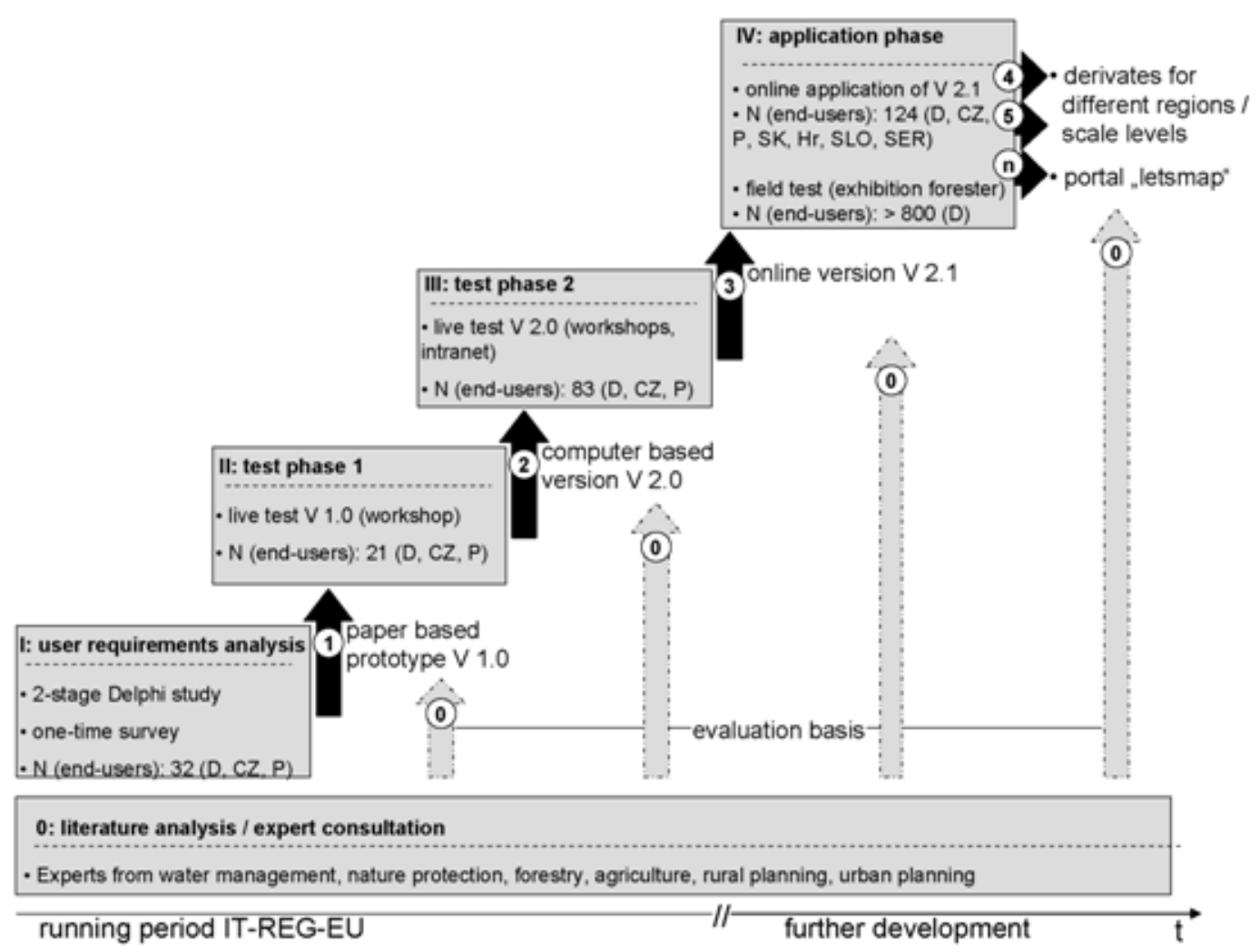

In a subsequent step, the Delphi study participants were asked to examine some exemplary tools and give their impressions on desirable design features. The analysis was designed as one-time survey (Borg and Gall 1989) and was in the form of an online questionnaire. The tools that the participants were asked to test were Cardogis, as example of a userfriendly Geographic Information Systems (GIS)based solutions (www.cardogis.com), Lenné3D, as an example of visualization tools (www.lenne3d.com ), Meascope, as an example of landscape management support in agriculture(www.mea-scope. $\underline{\mathrm{eu}}$ ), and SIAT as an example of a complex impact assessment and management support system (www .ip-sensor.org). Test examples and information on the tools and the underlying methods were presented on the webpage of the online questionnaire.

Again, a set of standardized alternatives for answers was offered, including the option of additional free comments (Tab. 1b). The following questions were posed:

(A2) Which are the most important application fields you see being supported?

(B2) Which features should the development focus on?

Based on the results of these two analyses and some freelanced ideas provided by the participants, a prototype of Pimp your landscape (V 1.0) was designed. This prototype was a paper-based version of the later system, which was tested to learn more about possible user habits. Testing of the prototype was carried out in a workshop. The participants were asked to simulate with the paper-based tool a typical communication and negotiation process in regional planning from the point of view of their professional experience in their sectors. In the simulated negotiation process, different land use pattern 


\section{Table 1. Overview of the results of the Delphi study.}

(A1) What kind of information sources are you generally using to prepare interdisciplinary planning decisions?

- textbooks, journals, other written information sources (handbooks, guidelines)

- oral information (consultation of experts and colleagues)

- institutional information systems

- web-based information/online portals

- other (newsletters, newspapers)

(B1) Which tools are you using to visualize the planning process and to support your decision?

- standardized Office applications (spreadsheets, calculator, etc.)

- (interactive) database applications

- maps and monitoring data (either in ditigal or printed form)

- institution specific software solutions (calculation programmes, visualization, etc.)

- key figures, operating figures

- handbooks, written guidelines

(C1) What do you think an optimal support system should look like? (Delphi round I)

- online portal including expert system and online consultation

- specialized/expert information system

- management software for free download

- decision schemes usable under standardized Office applications

- (digital) handbooks including (digital) decision tree(s)

1

2

3

4

5

6
(C1') What do you think an optimal support system should look like? (Delphi round II)

- online portal including expert system and online consultation

- specialized/expert information system

- collection of spreadsheets and key figures

- decision schemes usable under standardized Office applications

- management software for free download

-(digital) handbooks including (digital) decision tree(s)
$4.0(32)$ 
alternatives were proposed, evaluated, and discussed according to the divergent interests of the planning actors. The term "land use pattern" was used in the development of Pimp your landscape to express the mosaic of different land use types as they are classified in the context of CORINE Land Cover (CLC) 2000 or other land cover classification standards, for example, on a national level.

The experience using the prototype and desired improvements of the basic approach were analyzed in a feedback round. The results of this test formed the basis for finalizing the development profile for Pimp your landscape version V 2.0.

Several series of user tests were conducted in workshops and meetings as a means of refining the system and identifying development needs and technical weaknesses. The test series focused on questions regarding an optimal user interface and user support. Furthermore, the need for the system to correspond to different educational backgrounds and user skills was identified. The resulting online version $\mathrm{V} 2.1$ provides different modes of complexity; only the version with the highest level of complexity (scientific version) is presented in this article.

Subsequent tests revealed that the original approach to evaluating land use changes based only on information on land use types was too simple to reflect the complexity of the system landscape. This led to the development of a rule-based system concept, which also considered the question of neighborhood relationships between land use types, spatial restrictions, the impact of the localization of a land use type in the landscape, and temporal dynamics. Expert consultation and additional literature analysis are continued permanently for referencing the evaluation basis to prevailing studies and to fit the system to other regions.

A follow-up version of Pimp your landscape has been adapted for developing regional climate change mitigation strategies in the frame of the REGKLAM project (www.regklam.de) for the metropolitan areas of Leipzig-Halle-Bitterfeld and Dresden (Fürst et al., in press). An application for the development of forested regions has been tested and prepared for implementation in e-learning in the frame of the Leonardo da Vinci project TrainforEducation (http://foreducation.nlcsk.sk/de/ index.html). Finally, the tool and derivatives were integrated into a web portal ( www.letsmap.de ), which is under development for different user groups, user rights, and use cases.

\section{Land use classification and evaluation approach}

Pimp your landscape intends to use a generic approach for the evaluation and visualization of land use changes regarding environmental, economic, and social services. This requires the definition of a reference base for the land use classification, which ensures comparability between different countries, and between different regions within the countries. Furthermore, the experiences with the test subjects revealed that great attention should be paid to the development of a generic concept for the evaluation of the land use pattern changes with regard to their impact on land use services.

For this study, land use types were defined on the basis of the CLC 2000 classification because it was the only digitally available transnational planning basis at Euro Region Neisse. Apart from this studyspecific convention, Pimp your landscape can also import other kinds of digital data sets provided they are in vector format, as a shape or a text file. CLC 2000 offers many land use types, which were not all relevant in the model region. As a result, and in agreement with the participating experts, only the ten most important land use types were considered in the presented study.

With regards to the evaluation of land use change impacts, literature analysis was used to obtain information on comparable studies, whose outcomes can be transferred. Meanwhile, expert consultation was conducted to integrate unpublished regionally available data and information, and to fill some knowledge gaps where the literature analysis did not provide sufficient information. The experts consulted were those who participated in the Delphi study, and scientists in the fields of catchment area management and landscape aesthetics.

The evaluation idea is based on the LUFs framework (Perez-Soba et al. 2008, Schößer et al. 2009) but was modified for the purposes of this study. Based on the discussions at the regional workshops, the four regionally most important land use services were selected for Euro Region Neisse. The term "services" is used because the evaluation refers to 
appraisable landscape benefits. Taking the second service "ecology" as an example, the discussions revealed that possible alternatives, such as "biodiversity," "species diversity", or "habitat quality", were considered too narrowly defined and that the participants preferred a more holistic view on landscape services. The impact of each land use type on these services was evaluated as follows:

I. water quality with regard to the impact of a land use type on the nitrogen output as an indicator for drinking water quality. Expert consultation was used to put the different land use types in relation to each other for the scale level "region."

II. ecology with regard to the impact of a land use type on the regionally typical species richness. Administrative guidelines on the economic value of a land use (biotope) type were consulted (SMUL 2003). These guidelines are used for defining the extent of compensation measures for biotope losses by infrastructural measures.

III. economy with regard to the contribution of a land use type to income and taking into consideration the regionally relevant purchase prize relations. Statistical characteristics for land use type specific taxes, revenue ( $€$ / ha $\mathrm{x}$ a), and purchase prices were used (obtained from data of the statistics agency of Saxony, www.statistik.sachsen.de). This information was complemented by expert consultation for land use types for which no sufficient database was available (wetland, water bodies).

IV. aesthetics with regard to the contribution of a land use type to the aesthetical value of a landscape. Aesthetics was used as a proxy for the touristic value of the region. Regional studies on respective preferences of tourists were not available, but tourism was considered the most important landscaperelated issue in the region. Therefore, in the examples in the Results section, the term "tourism" is used, but this is based on the aesthetic value of the landscape. Expert opinion in combination with some literature on the aesthetic value of landscape elements and structures (Bourassa 1991, Wöbse 2003, Herrington 2008) were consulted.
To correspond to the demands of a generic evaluation concept and to achieve comparability between the different land use types and their services, a scale from 0 (= most negative effect) to 100 (= most positive effect) was introduced. The indicators and consulted knowledge sources were used to rank the land use types according to their impacts on this relative scale (Table 2). For upscaling the evaluation to the regional level, a weighted mean was calculated for each land use service by summing the values of each cell for the singular land use services and dividing the sums by the total number of cells. To exclude any influence of the evaluation result by impact factors such as cell size, the latter was fixed to $100 \times 100 \mathrm{~m}^{2}$.

\section{RESULTS - USER REQUIREMENTS AND SYSTEM CONCEPTION}

\section{User requirements}

The Delphi study showed that various kinds of information sources are used for knowledge mining without particular preference for a specific source (question A1). Information from publications and the consultation of colleagues or experts are used as extensively as web-based information and personal and institutional experiences, which are collected in sectoral information systems (Table 1).

In the planning and decision process, computerbased tools are clearly preferred to paper-based tools such as handbooks or written guidelines (question B1). Standardized Office applications, Geographic Information Systems, and interactive database applications are the most preferred instruments, followed by planning materials such as maps and monitoring data and institution specific planning software. Collections of key figures are still used for orientation, while handbooks and written guidelines were clearly ranked in last place (Table 1).

Preferences for an optimal support system focused on online portals and expert systems, while other alternatives such as a collection of spreadsheets and key figures, software or decision schemes and handbooks were ranked lower (question $\mathrm{C} 1$ ). Compared to the results of the first Delphi study round, the participants ranked online portals and 


\section{Table 2. Overview of the results of the one-time survey.}

Questions and alternatives $\begin{gathered}\text { Number of } \\
\text { answers }^{\dagger}\end{gathered}$\begin{tabular}{c} 
Ranking \\
\hline
\end{tabular}

(A2) Which are the most important application fields you believe need to be supported? Please clarify.

- other: communication and conflict negotiation in participatory processes

15

- landscape management planning (intersectoral)

- policy support/consulting

- impact assessment/estimation of potentials and risks in planning

- operational management and decision support (intrasectoral)

- other: further education and training

(B2) On which features should the development focus?

output - qualitative results (visualized results, e.g., maps, diagrams, trends for different planning

type alternatives)

- quantitative results (data (sets) or indicator sets as output to evaluate planning alternatives)

user $\quad$ free design of decision and management planning alternatives, user can generate rules and insight criteria and modify the evaluation basis

into results

generation

- modeling based results/simulation of landscape development, user input restricted to environmental data

- multicriteria decision making (MCDM), user input: decision criteria and data, optional choice between different MCDM methods

style of $\quad$ visualization of the relative benefit of different alternatives by using maps and information on

user guidance

to

decisions

21

14

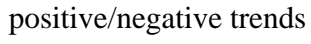

- Geographic Information Systems-oriented tool, which allows user to visualize planning alternatives and integrate multiple environmental information in decisions but is not too complex in handling and focuses on evaluation of scenarios

- comparison of different planning alternatives by (selected) indices

- proposition of the "best" alternative (decision making)

- decision tree
${ }^{\dagger}$ multiple answers were permitted; consequently, the number of answers given by the 32 participants in the study is $>32$ 
expert systems even more highly in the second round (question $\mathrm{Cl}^{\prime}$ ) (Table 1).

Table 1 presents the results of the two Delphi study rounds, including the originally proposed alternatives and additional comments and propositions by the participants, which are italicized. The evaluation results are displayed as weighted means calculated by the number of responses and the ranking given to each response alternative. Numbers in brackets give the number of responses.

The one-time survey gave information on the most important application fields for which the participants of the study expect improved support (question A2). The application field communication and conflict negotiation was ranked highest, followed by support in intersectoral planning processes and policy support. Impact assessment and decision support in intrasectoral planning were ranked lower. A few participants also proposed that management support systems be used in education and training (Table 2).

Considering the most important features the development should focus on (question B2), a trend could be identified with regard to qualitative information (output type) and high transparency in the way in which results are produced (user insight into results generation). The users voted for tools in the style of Geographic Information Systems, which focus on the visualization of planning alternatives and their effects (style of user guidance to decisions) (Table 2).

Table 2 provides information on the results of the one-time survey on envisaged application areas and demanded design features. Propositions by the participants are again italicized. The number of responses and the rankings are given. The participants had the option of choosing multiple answers.

Finally, in discussion with the Delphi study participants, a commonly accepted profile of the envisaged tool was defined that addresses the following generic attributes and specific features:

(i) An optimal support system should ensure a broad accessibility for users at any time and any place. A web-based solution was demanded.

(ii) The tool should offer the possibility to iteratively integrate experience from case studies and regional experts as well as upcoming scientific results into its knowledge base in terms of a learning system. The need to orient support as best as possible to realworld conditions and to the most recent knowledge was highlighted.

- $\quad$ As a precondition for broad acceptance and use, an interactive and self-explanatory user interface is expected. It was recommended that this interface be kept as simple as possible to ensure its suitability even for people who are not very familiar with the use of computers and electronics. This includes easy user guidance on how to adapt the evaluation to one's own experiences and upcoming knowledge. Information on the effects of what has been changed was expected to be available in real time.

- $\quad$ Based on the experiences from testing different tools and the prototype of Pimp your landscape, the following specific features were demanded by the test participants: (a) high ability to "design" the landscape and to introduce and modify planning rules, (b) easy handling of landscape changes in the system "by mouse click" without the necessity to learn a special programming language, and (c) transparency of the evaluation results and possibility to modify the evaluation basis.

In summary, an optimal solution was expected to be "a system in which different actors involved in planning decisions can share and exchange their planning propositions and which delivers generalizable conclusions on the effects of the planning alternatives for regionally important landscape services."

\section{Specifications for the system conception}

To address the user needs described in (ResultsUser Requirements and System Conception: User requirements), the software had to enable userdriven changes in the land use pattern by mouse click. Furthermore, it became necessary to evaluate the impact of the land use pattern changes on the most important land use services under consideration of complex interactions between various land use types and the related environmental conditions. Land use pattern changes are defined as 


\section{Table 2. Overview of the results of the one-time survey.}

Questions and alternatives $\begin{gathered}\text { Number of } \\
\text { answers }^{\dagger}\end{gathered}$\begin{tabular}{c} 
Ranking \\
\hline
\end{tabular}

(A2) Which are the most important application fields you believe need to be supported? Please clarify.

- other: communication and conflict negotiation in participatory processes

15

- landscape management planning (intersectoral)

- policy support/consulting

- impact assessment/estimation of potentials and risks in planning

- operational management and decision support (intrasectoral)

- other: further education and training

(B2) On which features should the development focus?

output - qualitative results (visualized results, e.g., maps, diagrams, trends for different planning

type alternatives)

- quantitative results (data (sets) or indicator sets as output to evaluate planning alternatives)

user $\quad$ free design of decision and management planning alternatives, user can generate rules and insight criteria and modify the evaluation basis

into results

generation

- modeling based results/simulation of landscape development, user input restricted to environmental data

- multicriteria decision making (MCDM), user input: decision criteria and data, optional choice between different MCDM methods

style of $\quad$ visualization of the relative benefit of different alternatives by using maps and information on

user guidance

to

decisions

21

14

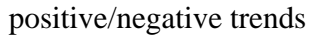

- Geographic Information Systems-oriented tool, which allows user to visualize planning alternatives and integrate multiple environmental information in decisions but is not too complex in handling and focuses on evaluation of scenarios

- comparison of different planning alternatives by (selected) indices

- proposition of the "best" alternative (decision making)

- decision tree
${ }^{\dagger}$ multiple answers were permitted; consequently, the number of answers given by the 32 participants in the study is $>32$ 
the conversion of (a) single land use types into another land use type, or (b) all land use types in a part of a region into a specific land use type. The first, (a), reflects regional planning measures such as the afforestation of agricultural sites or the conversion of coniferous forests into mixed forests; (b) reflects planning measures such as the establishment or enlargement of a settled area in a region. Therefore, the continuous problem "landscape" must be divided into spatially distinct units that can interact and communicate with each other and to which different attributes can be assigned.

Pimp your landscape was aligned with the approach of a cellular automaton with a Moore neighborhood (nine-cell neighborhood with range $r=1$ : http://ma thworld.wolfram.com/MooreNeighborhood.html). According to Cochinos (2000), "a cellular automaton is a discrete dynamical system. Each point in a regular spatial lattice, called a cell, can have any one of a finite number of states. The states in the cells of a lattice are updated according to a local rule. That is, the state of the cell at a given time depends only on its own state one time step previously, and the states of its nearby neighbors at the previous time step. All cells in the lattice are updated synchronously. The state of the lattice advances in discrete time steps."

Cellular automata were introduced by Ulam (1952), and their potential to support the understanding of the origin and role of spatial complexity was highlighted by Tobler (1979). The original cellular automaton concept has been adapted for modeling urban structures and land use dynamics (White and Engelen 1993, 1994, White et al. 1997, Barredo et al. 2003), regional spatial dynamics (White and Engelen 1997), and the development of strategies for landscape ecology in metropolitan planning (Silva et al. 2008). Nowadays, cellular automata are broadly used to simulate the impact of land use (pattern) changes and landscape dynamics (e.g., Soares-Filho et al. 2002, Holzkämper and Seppelt 2007, Yang et al. 2008, Moreno et al. 2009, Wickramasuriya et al. 2009).

Pimp your landscape has adopted some properties of the cellular automata concept in land use modeling but has also modified some aspects. The cell is the smallest spatial unit in the system with invariable size (actually $100 \times 100 \mathrm{~m}^{2}$ ) and interacts with its neighboring cells in accordance with certain rules. Contradictory to the original concept of a cellular automaton, each cell can have multiple attributes as introduced by Couclelis (1997). The land use type is the most important cell attribute and the only one that is updated. Pimp your landscape does not automatically update all cell states on the basis of rules, but the user has to decide (by mouse click), at which point in time he wants to change a cell or a part of the region. Rules for restrictions and for evaluating the effects of updating the land use types are explicitly defined by the user (ResultsUser Requirements and System Conception: Rule setting options) and consider the cell state, the states of neighboring cells, cell attributes such as environmental data, the presence or absence of linear (e.g., streets, rivers) or point-shaped elements (e.g., power plants), and thresholds for the maximum or minimum share of a land use type. User-driven and nonautomatic updating was chosen to increase the transparency of the outcomes of the evaluation, as the user can then directly experience the effects of each change that is being carried out. A better term to reflect the way in which Pimp your landscape is working would probably be "cellular semiautomata."

\section{Evaluation results}

Literature analysis and expert consultation was used to create an evaluation table that ranks the impact of each regionally important land use type on the most important land use services on a scale from 0 to 100. Table 3 shows as an example the resulting regional evaluation table for Euro Region Neisse. This table is exclusively valid for the considered model region. For other regions, the considered land use types and services and the related evaluation must be adapted on the basis of regional knowledge sources and experiences.

The evaluation table forms a major steering mechanism for the user, who can change and adapt this table according to regional demands, existing knowledge, and consulted experiences. A special user interface allows the user to generate a stepwise evaluation, starting with the selection and description of the land use types. CLC 2000 is available as a standard set, but a user-specific set can also be introduced. This step is followed by the selection of the land use services. The LUF set is available as a standard set, but again, a user-specific set can also be introduced. After having finished these two steps, a matrix is displayed, where values from 0 to 100 have to be entered for each land use 
Table 3. Exemplary evaluation table for the Euro Region Neisse.

\begin{tabular}{lcccc}
\hline \hline & \multicolumn{2}{c}{ Values of the land use types for the land use function } \\
\cline { 2 - 5 } $\begin{array}{l}\text { CORINE Land Cover 2000 land } \\
\text { use types }\end{array}$ & Water quality & Economy & Ecology & Aesthetics \\
\hline urban areas & 0 & 100 & 0 & 0 \\
industry & 0 & 100 & 0 & 0 \\
agriculture & 20 & 80 & 30 & 20 \\
fruit trees and vegetables & 30 & 75 & 35 & 40 \\
pastures & 60 & 60 & 35 & 50 \\
deciduous forests & 80 & 30 & 100 & 80 \\
coniferous forests & 50 & 40 & 60 & 60 \\
mixed forests & 80 & 35 & 90 & 90 \\
natural grassland & 70 & 5 & 100 & 90 \\
wetlands and waterbodies & 100 & 5 & 100 & 100 \\
\hline
\end{tabular}

type - land use service combination. In this matrix, the maximum values must be entered, which a land use type can adopt considering its impact on a land use service in the specific regional context: for the application of the system and with regard to the data basis for the evaluation, it was necessary to refer to planning units with practical relevance. Therefore, Pimp your landscape refers to concrete regions whose borders are at the moment predefined (set of model regions). A region is understood to be a spatially confined area, and is classified by its land use pattern (mosaic of land use types, e.g., forested regions, agricultural regions, urban regions, etc.) and additional environmental factors (climate zones/geo-zones). Land use pattern and environmental factors determine the maximum value of a land use type considering its contribution to the provision of land use services. As a result, the transfer of an already developed evaluation and rule set from one region to a comparable one is possible.

The rules described in the next section were built on the evaluation table.

\section{Rule setting options}

A number of rule-setting routines was implemented in the system. These offer the opportunity to define in detail the interactions between neighboring land use types and the impact of environmental frame conditions on the cell-specific values of a land use type for a land use service. Furthermore, planning restrictions can be described by these rule-setting routines (Fig. 2).

Each rule must be saved with a name and must be documented by a short description. Once a rule is established, it can be activated or deactivated. A rule is always valid for the region where it was established and is therefore based on the regionspecific evaluation table. For use in other (comparably classified) regions, the evaluation table and the rule systems can be exported. The following rule setting options are given:

\section{Impact of environmental frame conditions}

I.1 Based on the evaluation table, the user can specify if and to which percentage cell attributes 
Fig. 2. Connection between value table, rule sets, and evaluation results in Pimp your landscape.

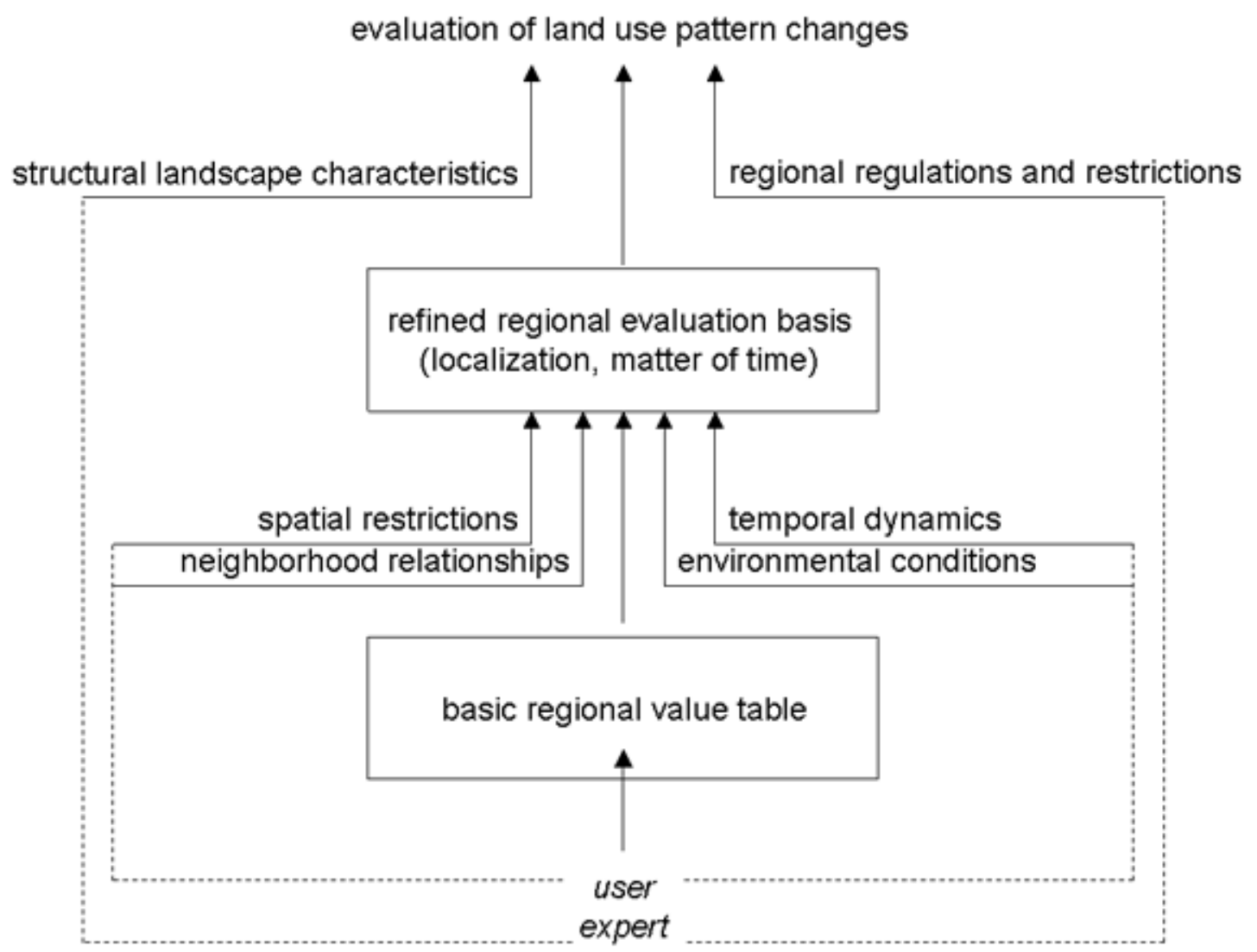

such as geological and topographical data, climate data, etc., reduce the value of a land use type for a land use service. Note that in the evaluation philosophy of Pimp your landscape, the basic value of a land use type for a land use service represents the maximum in the regional context. Cell attributes can only reduce this maximum value. The specific local situation of a cell within a region can thus be integrated in the evaluation and helps to provide a more realistic appraisal of the impact of changes in land use patterns. An example is the economically relevant productivity of agricultural or forest areas as being dependent on the height above sea level (length of the vegetation period), the soil potential, and the available annual precipitation.

I.2 Furthermore, the user can define whether one of the above-mentioned cell attributes restricts the possibility of converting a land use type into another (see I.1). In this rule-setting option, two aspects are integrated: (a) the probability that an environmental factor limits the conversion of a land use type into another, and (b) considerations of regional planning restrictions that might forbid the conversion of one land use type into another. An example is (a) the probability that badlands can be converted into forests or agricultural sites as dependent on the soil type or the mean annual precipitation. Steep slopes in mountainous areas can serve as an example for (b), as forests should be kept there to protect the site (protection forests).

\section{Interactions between cells}

II.1 In this rule-setting routine, the user has the option of specifying if and at which percentage the value of a land use type for one (or several) land use service(s) is decreased by the neighborhood to another land use type. In the simplest case, two cells of the same land use type are in direct proximity. 
As a result, no mutual impact is assumed. In the case that two differing land use types are neighbors, their original value for one (or several) land use service (s) might decrease. As an example, the value that is assumed for an agricultural site in terms of its economy can be reduced by its proximity to a forest due to its shadowing effects. At the same time, the economic value of the forest might increase due to its proximity to an agricultural site providing nitrogen deposition. Following the model of a Moore neighborhood, different neighborhood types are considered. A longitudinal neighborhood has a full impact, whereas the impact is reduced as a commitment to $25 \%$ of the full value in the case of the diagonal proximity of the cells.

II.2 Furthermore, the user can define whether a neighborhood restricts the possibility of the conversion of a land use type. This rule-setting option reflects planning restrictions that might occur. As an example, it might be forbidden to establish a dump site in the neighborhood of a settlement.

\section{Interactions between cells and linear or point- shaped elements}

III.1 The user can specify if and at which percentage linear or point-shaped cell attributes reduce the value of a land use type for one or several land use services. In the case of point-shaped elements, the user must specify the spatial distance up to which this impact is valid. This is the only case where the Moore neighborhood with range $r=1$ is modified. An example is the impact of a power plant, for which a deposition gradient must be defined. The spatial distance and the number of neighbors that are affected in each direction are simply defined by freehand delineation on the map. The gradient can be centric or irregular, even with an excentric localization of the point-shaped element. Within the gradient, a linear decrease of the impact is assumed starting with the highest impact on the original values of the land use types at the cells nearest to the point-shaped element.

III.2 In addition to the rule-setting option described in II.2, the user can specify whether the existence of and neighborhood to linear elements, such as rivers or roads, restricts the conversion of a land use type into another. "Existence of" addresses the cells that have a river or road as an additional cell attribute; "neighborhood to" addresses cells that are situated next to a cell with such an attribute. As an example, the clearing of forests along rivers can be forbidden and reflects the planning restriction to protect floodplain forests.

\section{Further rule setting options reflecting planning restrictions}

IV.1 A basic characteristic of a cellular automaton is the transition probability of the original status of a cell into another status. Independent from the yetdescribed impact of the neighboring land use type (II.2), the user can specify which land use type is basically allowed to be converted into another. This reflects again two aspects: (a) the (natural) probability that a certain land use type can be converted into another, and (b) the considerations of regional planning restrictions, which might forbid the conversion of one land use type into another. An example for (a) is the conversion of a settlement into a forest; an example for (b) is the conversion of a deciduous forest into a coniferous forest.

IV.2 To support the complex considerations in regional planning, the user can also specify development thresholds and development trends. The minimum and maximum share of a land use type with reference to the total number of cells can be defined. Additionally, the user can decide whether the actual share of a land use type can only be increased or decreased or must be kept. This reflects planning aspects with regard to the character of a landscape. As an example, it might be desirable to keep the character of a cultural landscape with a share of 30-40\% of forests, $50-60 \%$ of agriculture, $5 \%$ of water bodies, and a maximum of $5 \%$ of noncontinuous urban areas. In this case, only the location of the different land use types could be changed, but a warning message would signal whether one of the thresholds is exceeded. In progress is a complementary option to decrease the value of a land use type for one or several land use services as a function of these thresholds.

IV.3 Finally, the user can also set minimum or maximum thresholds for the land use services on a scale from 0 to 100 . This offers the option to reflect political targets in planning, such as keeping biodiversity or water quality at a certain level.

\section{$V$. Impact of time on the evaluation result}

The value of a land use type for one or several land use services might depend on its development stage. 
An example is the afforestation of former agricultural sites: at least one forest stand life is necessary until the full quality of the forest ecosystem is reached in terms of drinking water quality, typical species richness, and economically relevant production. The consideration of a time dependent value of land use types for land use services is also important for evaluating land use pattern changes for climate change scenarios with different speeds and intensity of changes over time. The user can decide for which land use types such trends apply, and must define first which time periods should be considered in the evaluation and next the time-dependent value of the land use type for the land use services, for which temporal trends are relevant.

The different rule-setting options can be used singularly, or several rules can be combined and saved as a complex rule set. An example of a complex rule set is the translation of multiple planning restrictions derived from EU directives such as Natura 2000 or the EU Water Framework Directive. The possibility of combining rules enables the comparison of the functioning and effects of competing directives or planning restrictions.

The rules impact the possible land use pattern changes in different ways: (a) the evaluation result is dependent on the rules I.1, II.1, III.1, and V (and in future also IV.2); (b) the number of land use types that are displayed in a selection box when clicking on a cell can be limited by rules I.2, II.2, III.2, and IV.1; and (c) warning messages are given if thresholds defined in rules IV.2 and IV.3 are broken.

\section{Technical realization and usage of the system}

Pimp your landscape (V 2.1) was developed as an online tool. Information on land use patterns was based on CLC 2000 maps with a spatial resolution of $100 \times 100 \mathrm{~m}^{2}$ (= 1 cell). This resolution was chosen because it is the highest resolution possible with CLC 2000. Roads, highways, railways and water bodies are displayed as linear elements, which are extracted from 1:100 000 topographic maps. Additional attributes such as geology/soil type, topography, and climate data can be imported in the form of vector data (text or shape file) as an information layer, which is valid for the total region. If no relevant information is available, these cell attributes can also be defined manually for each cell or for an area comprising several cells. To avoid the user's confusion as a result of information overflow, only land use pattern and infrastructural elements are displayed as maps at the front end, while information on the additional attributes is displayed as pop-up window when the cursor hovers over a cell.

One of the major development challenges involved combining of permanent map details (existent infrastructural elements, environmental attributes) and modifiable map details (land use types, additional linear or point-shaped infrastructural elements) without using GIS functionalities, which are highly complex and time demanding. Each cell must contain geo-referenced information about the major land use types and the presence or absence of other attributes. A color code management enabling the identification, administration, and allocation of colors to each cell was thus introduced. A mapmanagement module supports the relation of the CLC 2000 land use maps and the attributes from the other information layers to the same scale without distortion. The described data aggregation technology allows for an optimized loading time of the maps and for the fast actualization of the land use pattern and the insertion of linear or pointshaped elements per mouse click. Additionally, zoom functionality is supported, which helps users adapt the user interface optimally to their technical facilities (screen size). The possibility of working with different raster sizes from 1 x 1 (= basic resolution of $100 \times 100 \mathrm{~m}^{2}$ ) up to $16 \times 16$ and with a freehand mode for enabling large-scale changes is another result of this special aggregation technology.

Figure 3 shows the home page of Pimp your landscape. The maps displayed on the user interface are divided into $10 \mathrm{x} 10 \mathrm{~km}$ sections and transferred into gif format to reduce the transfer time to the endusers' browsers. The user is asked to zoom into regions - that is, to select a part of the region that he/she wants to work on, by mouse click. This was done for practical reasons, as tests showed that users are not able to work on more than 2500 to 3000 cells simultaneously. It is also possible to upload a map together with environmental data sets, which are available as a text or shape file in a resolution of $100 \times 100 \mathrm{~m}^{2}$ (without illustration).

Figure 4 shows the actual user interface of Pimp your landscape. For each of the $100 \times 100 \mathrm{~m}^{2}$ cells, the dominant land use type is displayed. 
Fig. 3. Home page of Pimp your landscape, displaying some of the model regions, which are already integrated into the system.

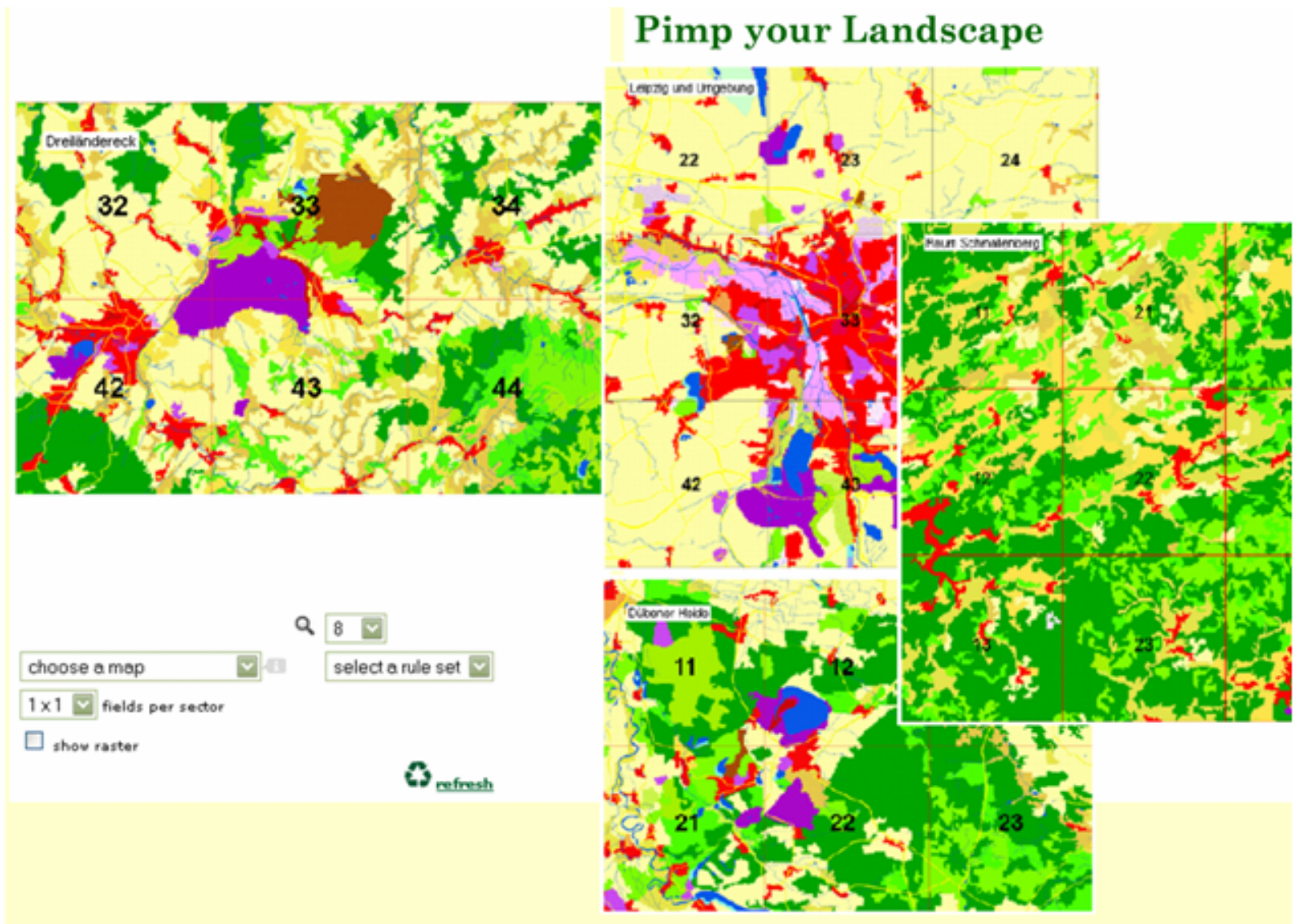

After having selected a region and the related data sets and having specified the rules in the menus above the map, the user is offered multiple tools to modify the landscape, which are shown by icons. The icons below the map, from left to right, allow for changing the land use types cell-wise, for changing a sector marked by a freehand delineation, for changing all cells of a certain type, which are neighbored at a stretch, and for changing all cells of a certain land use type for the whole map. A new land use type is assigned by a pop-up menu, which displays the available land use types. A click on the desired land use type (e.g., coniferous forest) makes the intended change.

The fifth icon below the map allows for delineating streets with different sizes (highways, main roads, small roads, etc.). Different classes of streets according to their size and traffic intensity can be selected from a pop-up menu, and the impact on the land use services must be specified by the user for each of the classes. The sixth icon gives the same opportunity for rivers. The seventh icon enables the delineation of water bodies. The eighth icon allows the user to zoom into a part of the map and to compare the evaluation results, which are displayed in a star diagram (faded out in the illustration) for the total map and for the selected zoom area. This feature helps one to better understand local effects, for example, such as those associated with the introduction of a motorway junction or the introduction of a dumpsite. It is also possible to switch between different zoom areas, for example, to test the effects of introducing a dumpsite or motorway junction at alternative localizations in the map. The last icon below the map allows for drawing 
Fig. 4. User interface of Pimp your landscape.

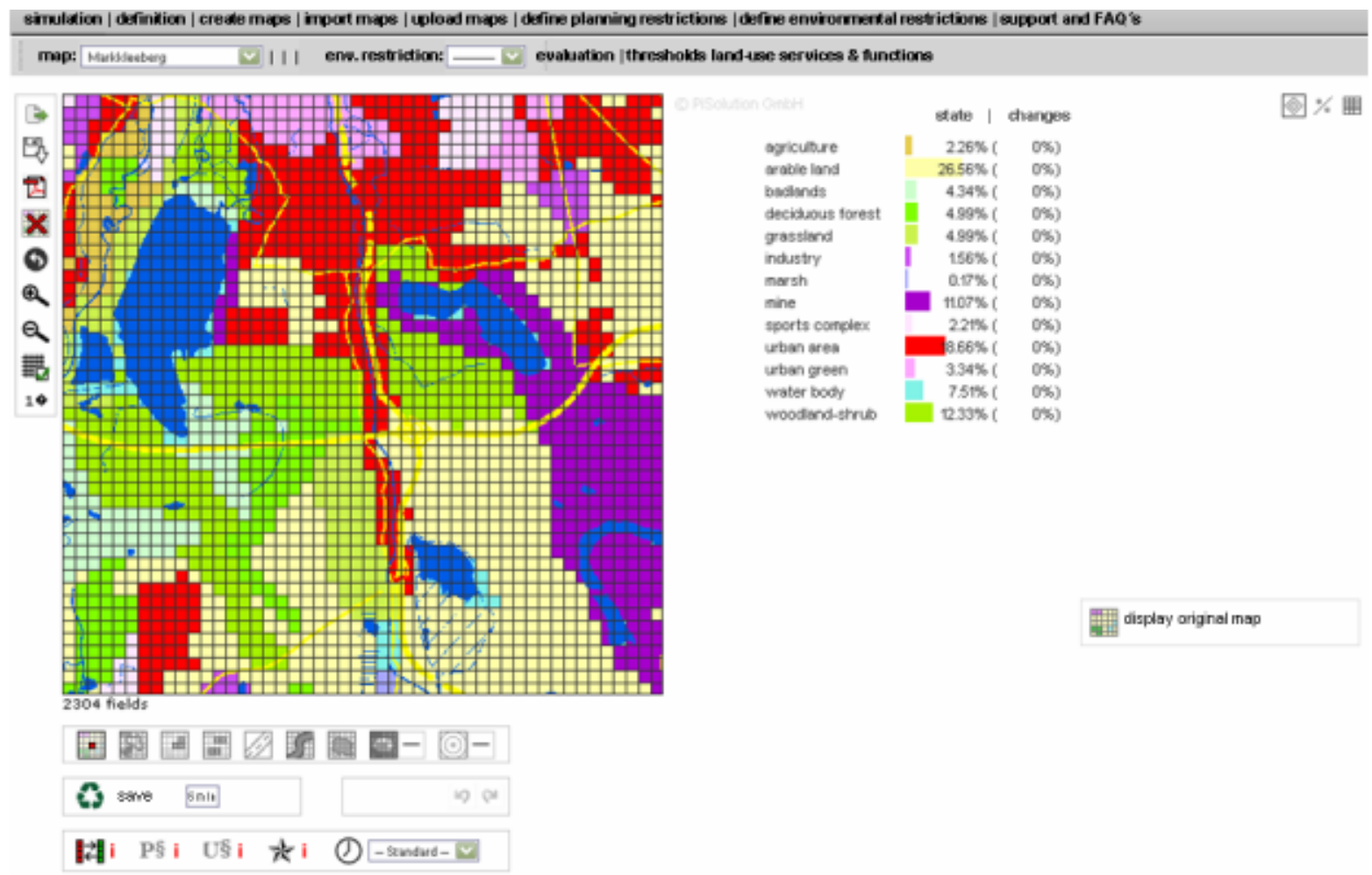

a point-shaped element in the map and to define its impact gradient. The icons in the row below this provide the opportunity to save the results of the simulation and to receive information on the rule sets that are introduced and activated. The clock icon provides the opportunity to activate a menu, where values of the land use types for one or several land use services can be defined as dependent on different time slots.

The tool bar on the left-hand side of the map from top to bottom includes icons for exporting the final results of the simulation as a text or shape file and for saving them as a pdf file. The fourth icon allows the user to reset the simulation. The fifth icon activates the replay of all movements so far, and can be interrupted to restart the simulation at a move that might have led to undesired results. The two icons below that allow the displayed map size to be enlarged or reduced. The next-to-last button activates or deactivates the display of the raster, and the last icon allows the displayed raster size to be changed. This is thought to be useful in cases where a user wants to convert larger parts of the map with homogenous cells. It does not affect cells sized 100 $\mathrm{x} 100 \mathrm{~m}^{2}$.

A legend, which can be activated by mouse click, informs the user about the colors of the land use types and their regional value on a relative scale from 0 to 100 . For the displayed map, a statistic of the land use types can be displayed (right-hand side of the map), or evaluation results can be displayed in a star diagram or a trend table that gives the numbers and shows the trends for the land use services as indicated by arrows (icons on the righthand side of the statistic). The numbers, which are displayed in the star diagram and the trend table, are the weighted mean values for each land use service (Introduction). 
To support the visual comparison of the original landscape and the simulation result, the original situation can be displayed in parallel to the map by clicking the "display original map" icon on the righthand side of the map. The figure that is displayed cannot be changed by the user, but its position can be moved with the mouse to avoid obscuring the diagram, trend table or land use type statistic.

\section{DISCUSSION}

\section{Complexity versus simplicity - advantages and disadvantages}

Systems for supporting spatial management decisions were developed in the frame of many projects. The application fields they cover range from sectoral management support in forestry up to integrated water resources and complex environmental management approaches (Matthies et al. 2007, Burstein and Holsapple 2008a, 2008b, Reynolds et al. 2008). However, a major criticism of these systems is their high complexity, which provides an abundance of information far beyond what is really used by managers or even policy makers (Uran and Janssen 2003, Van Kouwen et al. 2008). Meanwhile, the need to pay greater attention to enduser needs and to the requirements of particular applications of a tool is widely recognized (Giupponi 2007). Mendoza and Prabhu (2005) and Parker et al. (2008) have identified the human aspect and especially communication as central criteria for the development of successful system solutions. Communication in this context must comprise both the internal communication between the developers and the external communication with end-users. How does one evaluate Pimp your landscape with this background in mind?

Pimp your landscape was conceived as an instrument to visualize the effects of changes in land use pattern and to quickly provide information on possible positive or negative trends. The intention is to support a better understanding of the effects of spatial planning measures at the landscape level. Pimp your landscape allows for the flexible consideration of different land use change scenarios and the quick visualization of possible side effects and trade-offs. The tool can easily be adapted to any region considering the land use services to be integrated, the digital data (maps) to be used, and the available evaluation basis and rule sets to be introduced. Consequently, the original aim to realize a generic system approach, which can be adapted to variable application cases, was achieved. (Holzkämper and Seppelt 2007).

One of the main development targets of the tool is to deliver a basis for exchange, discussion, and conflict solution between different actors or actor groups in regional planning. The system conception, its development, and the configuration for its application fields is driven by end-user demands from the beginning on. This was done especially with regard to the criticism about spatial support systems highlighted by Uran and Janssen (2003).

The intention to build the system development basically on the users' point of view led to some problems. A problem was to concretize the user demands because the participating experts in the Delphi study were not very familiar with existent and available solutions and thus could not always specify in detail what they really understood to be an optimal solution. Therefore, the one-time survey was added, and the experts were offered the opportunity to have a look at existing solutions and to test them. A problem in the user-driven development was that users could not or were not willing to spend much time testing different solutions, and their answers thus remained partially superficial. In consequence - and diverging from the original intention of a completely user-driven approach - the initial system specifications had to be proposed by the developers and had to include their experiences (and probably preferences). Communication within the development team, with the end-users, and also with scientists working in the field of developing support systems at different scale levels was an essential element in the development of the software. In particular, exchange with other scientists, with regard to experiences with user-driven software development, will increase in the future as a result of lessons learned from the development process so far.

User needs with regard to new knowledge and their being addressed by simplified answers and scientific progress are currently unmatched. A precondition for a successful support tool is the strict orientation on the knowledge background and skills of the later user (Diez and McIntosh 2009) and the transparency of the results (Malczewski 2004). Therefore, it was considered essential to keep the evaluation approach and the output on the effects of land use pattern changes as simple as possible. In consequence, Pimp your landscape is not based on 
coupled models and gives a very simple set of feedback to the user. The evaluation results represent highly aggregated information corresponding to the demands of decision and policy makers (Hartono et al. 2007). The selected approach of a cellular (semi)automaton provides a useful instrument to consider complex interactions at the landscape level (Holzkämper and Seppelt 2007, Silva et al. 2008), but it is also useful to make them more transparent for the user.

With regard to the manifold evaluation approaches and results in environmental impact assessment (Perez-Soba et al. 2008), the applied approach of using a combination of literature analysis and expert consultation for the evaluation basis and to reference the impact of land use types on all land use services on a scale from 0 to 100 runs the risk of presuming the accuracy and simplicity of answers that, in fact, do not correspond to the complexity of real-world conditions.

The analysis of appropriate knowledge sources and indicators for the evaluation has also revealed a severe problem: when bundling experience-based expert knowledge and knowledge from publications on the impact of different land use types on landscape services, an incredibly high number and variability of indicators and indicator sets were found for the effects of each single land use type on the land use services (e.g., Repetti et al. 2006). Furthermore, indicators and indicator sets do not deliver in any case a sound basis for comparing different land use types and achieving an integrative evaluation at the landscape level (Yli-Viikari et al. 2007, Wijewardana 2008). This required an intensive selection process and complicated referencing of the land use impacts on the described scale from 0 to 100 . A possibility would have been to directly display the indicators or indicator sets as feedback for the end-user. However, this endangers the comprehensibility of the results for users, in this case especially the non-professional ones (e.g., Janssen et al. 2006). The relative ranking of land use types also has another advantage over the direct display of indicators. When using a set of indicators and knowledge sources for each land use type and service, the ranking becomes more stable over time compared to each single indicator (compare e.g., Lindeijer 2000). On the other hand, the chosen referencing of the results on a relative scale might reduce the transparency of the results. A solution corresponding to both needs, the quick estimation of positive/negative trends and more detailed information on the underlying indicators and indicator sets is planned to be implemented soon.

Another possible constraint faced in the acceptance and use of Pimp your landscape is a missing interface for land use type specific or landscaperelated models. The reasons for this are that analyses of existing systems and modeling approaches have shown that the availability of models for all land use types that consider multiple effects on different land use services is not ensured (e.g., Rossing et al. 2007). Furthermore, models of different land use types often work at different scales, which complicates their linking in a landscape leveloriented system. Models are often hyperparameterized, which confines their use to regions that were originally developed. Last but not least, few models cover the interactions between land use types in a landscape context (e.g., Lambin et al. 2000, Roetter et al. 2005, Verburg et al. 2006). As a result, Pimp your landscape was conceived as open platform, which supports the integration of knowledge gained from modeling results but also offers the possibility of compensating missing knowledge with experiences and expert knowledgebased estimation. The future direct linking to models, however, is not excluded.

To validate the results of Pimp your landscape, a comparison with spatial modeling approaches is in preparation in the context of the project REGKLAM (www.regklam.de), and focuses first on the water quality, economic, and (in development) soil protection (erosion risk) land use services. The consideration of landscape structure indices in the evaluation results is actually integrated into the validation of the outcomes for services such as ecology (diversity) and aesthetics. As a result, comparison with the outcomes of other approaches has not yet begun.

The presented options to specify rules and thresholds are intended to partially compensate for the missing link to models. However, in discussion with the test persons, two criticisms occurred: the intention to provide great flexibility to the user in adapting and defining unique rule sets demands, at least at the beginning, a time-consuming adaptation of the system, despite the offer that predefined evaluation tables and rule sets for some model regions are iteratively integrated into the system and are made available for the users. The other criticism is the possible misuse of the software by inaccurate rule settings, which might produce incorrect results. 
These criticisms are valid, and they restrict the free use of the software without accompanying scientific support. Furthermore, user groups are specified with differentiated rights to adapt and configure the knowledge base and restrictions.

\section{CONCLUSION AND OUTLOOK}

Pimp your landscape supports the testing, visualization, and evaluation of the effects of changes in land use patterns, which result from spatial planning measures. The advantage of Pimp your landscape is its simple entry and online handling with low technical requirements with regard to end-users' technical facilities (Seffino et al 1999, Tang and Waters 2005). In fact, a widely available set of maps based on CLC 2000 and geographical, topographical, and climate data sets is used as a standard. For each new region, these data sets can easily be imported into the system's map management module. A possible extension to CLC 2000 would be offered by the GEOLAND data sets (Willemen and Kooistra 2004), which so far are available for only some regions. The vision for future development, however, is to link Pimp your landscape with open access map material or satellite data (e.g., Google Earth). A link to OpenStreetMap is already realized, and even the option to overlay the maps with orthophotos is tested.

The system also offers the user the possibility to go in-depth, specifying complex planning restrictions and testing variable planning measures. The main application fields of the system are training and education in understanding the effects of spatial planning measures and the interactions of different land use types at a landscape level. Furthermore, the software can be used for the initial estimation of possible positive or negative consequences of planning measures at the landscape level. Last but not least, Pimp your landscape also supports the stepwise identification of possible planning corridors for infrastructural planning by delivering a forum of exchange and discussion between different actors in spatial planning.

The development of Pimp your landscape with user requirements analysis, test series, and feedback rounds is ongoing in a number of projects on the national and EU-wide levels. Different application fields are currently being tested. On a microscale level, Pimp your landscape is used to design together with regional citizens ways of using and developing former opencast mining areas in the vicinity of Leipzig. Another application area on a microscale level is to test together with farmers alternative scenarios of land consolidation measures in the catchment area of a drinking water reservoir. On a meso-scale level, the system is used to test the effects of different land use pattern alternatives under a climate change scenario to develop a mitigation strategy for the metropolitan region of Dresden. Furthermore, the software is applied in Brazil to moderate land use management conflicts in the vicinity of the capital city of Brasilia. The system is also used for the education and training of land use managers in the context of a Leonardo da Vinci activity in Austria, Czech Republic, Germany, and Slovakia.

Responses to this article can be read online at: http://www.ecologyandsociety.org/voll5/iss3/art34/ responses/

\section{Acknowledgments:}

The authors wish to acknowledge first the numerous participants in the studies. The development of the system was carried out in the frame of the INTERREG-III-a project IT-REG-EU (SN-06-J3-1D1287 ERN) and the project ENFORCHANGE of the German Federal Ministry of Education and Research $(0330634 \mathrm{~K})$. The authors also wish to thank the reviewers for their helpful comments, and Carsten Lorz (TU Dresden) and Martin Volk (UFZ) for support of the system development and fruitful discussions on developing the methodological approach.

\section{LITERATURE CITED}

Barredo, J. I., M. Kasanko, N. McCormick, and C. Lavalle. 2003. Modelling dynamic spatial processes: simulation of urban future scenarios through cellular automata. Landscape and Urban Planning 64(3):145-160.

Bengtsson, J., S. G. Nilsson, A. Franc, and P. Menozzi. 2000. Biodiversity, disturbances, ecosystem function and management of European forests. Forest Ecology and Management 132 (1):39-50. 
Borg, W. R., and M. D. Gall. 1989. Educational research: an introduction. Fifth edition. Longman White Plains, New York, New York, USA.

Bourassa, S. C. 1991. The aesthetics of landscape. Belhaven Press, London, UK.

Burstein, F., and C. W. Holsapple, editors. $2008 a$. Handbook on decision support systems 1. Springer, New York, New York, USA.

Burstein, F., and C. W. Holsapple, editors. $2008 b$. Handbook on decision support systems 2. Springer, New York, New York, USA.

Cochinos, R. 2000. Introduction to the theory of cellular automata and one-dimensional traffic simulation. [online] URL: http://www.theory.org/c omplexity/traffic/.

Cooke, R. M. 1991. Experts in uncertainty: opinion and subjective probability in science. Oxford University Press, Oxford, UK.

Couclelis, H. 1997. From cellular automata to urban models: New principles for model development and implementation. Environment and Planning B 24:165-174.

Dalkey, N., and O. Helmer. 1963. An experimental application of the Delphi method to the use of experts. Management Science 9(3):458-467.

Diez, E., and B. S. McIntosh. 2009. A review of the factors which influence the use and usefulness of information systems. Environmental Modelling and Software 24(5):588-602.

Dorren, L. K. A., F. Berger, A. C. Imeson, B. Maier, and F. Rey. 2004. Integrity, stability and management of protection forests in the European Alps. Forest Ecology and Management 195 (1-2):165-176.

Dragosits, U., M. R. Theobald, C. J. Place, H. M. ApSimon, and M. A. Sutton. 2006. The potential for spatial planning at the landscape level to mitigate the effects of atmospheric ammonia deposition. Environmental Science and Policy 9(7-8):626-638.

Evaluation of Socio-Economic Development (EVALSED). 2003. Sourcebook 2: methods and techniques. Directorate-General for Regional Policy, European Commission. [online] URL: http: //ec.europa.eu/regional policy/sources/docgener/ evaluation/evalsed/sourcebooks/method techniques/ index en.htm.

Fürst, C., C. Davidsson, K. Pietzsch, M. Abiy, F. Makeschin, C. Lorz, and M. Volk. 2008. "Pimp your landscape" - interactive land use planning support tool. Pages 219-232 in U. Mander, C. A. Brebbia, and J. F. Martin-Duque, editors. Geoenvironment and Landscape Evolution III. WITpress, London, UK.

Fürst, C., G. Nepveu, K. Pietzsch, and F. Makeschin. 2009. Comment intégrer des considérations multicritères dans la gestion d'un territoire ? "Pimp your landscape" - un essai de planification interactive pour satisfaire les besoins des utilisateurs. Revue forestière française 1:21-36.

Fürst, C., K. Pietzsch, C. Lorz, and F. Makeschin. In press. Integration of environmental processes into land-use management decisions. Process management, Intech publisher, Vienna, Austria.

Gardner, R. H., and D. L. Urban. 2007. Neutral models for testing landscape hypothesis. Landscape Ecology 22(1):15-29.

Giupponi, C. 2007. Decision support systems for implementing the European Water Framework Directive: the MULINO approach. Environmental Modelling \& Software 22:248-258.

Haigh, M. J., L. Jansky, and J. Hellin. 2004. Headwater deforestation: a challenge for environmental management. Global Environmental Change $\mathbf{1 4}$ (1):51-61.

Hartono, E., R. Santhanam, and C. W. Holsapple. 2007. Factors that contribute to management support system success: an analysis of field studies. Decision Support Systems 43(1):256268.

Helming, K., H. Bach, O. Dilly, R. F. Hüttl, B. König, T. Kuhlmann, M. Perez-Soba, S. Sieber, P. Smeets, P. Tabbush, K. Tscherning, K. Müller, D. Wascher, and H. Wiggering. 2008. Ex-ante impact assessment of land use changes in European regions - the SENSOR approach. Pages 56-77 in K. Helming, M. Perez-Soba, and P. Tabbush, editors. Sustainability impact assessment of land use changes. Springer. Berlin, Germany. 
Herrington, S. 2008. On landscapes. Routledge, New York, New York, USA.

Holzkämper, A., and R. Seppelt. 2007. A generic tool for optimizing land use patterns and landscape structures. Environmental Modelling \& Software 22:1801-1804.

Janssen, M. A., H. Goosen, and N. A. Omtzigt. 2006. Simple mediation and negotiation support tool for water management in the Netherlands. Landscape and Urban Planning 78(1):71-84.

Jessel, B., and J. Jacobs. 2005. Land use scenario development and stakeholder involvement as tools for watershed management within the Havel River Basin. Limnologica - Ecology and Management of Inland Waters 35(3):220-233.

Kallioras, A., F. Pliakas, and I. Diamantis. 2006. The legislative framework and policy for the water resources management of trans-boundary rivers in Europe: the case of Nestos/Mesta River, between Greece and Bulgaria. Environmental Science and Policy 9(3):291-301.

König, H., J. Schuler, U. Suarma, D. McNeill, J. Imbernon, F. Damayanti, S. A. Dalimunthe, S. Uthes, J. Sartohadi, K. Helming, and J. Morris. 2010. Assessing the impact of land use policy on urban-rural sustainability using the FoPIA approach in Yogyakarta, Indonesia. Sustainability 2(7). doi:10.3390/su2071991

Lambin, E. F., M. D. A. Rounsevell, and H. J. Geist. 2000. Are agricultural land use models able to predict changes in land use intensity? Agriculture, Ecosystems and Environment 82(1):321-331.

Letcher, R. A, and C. Giupponi. 2005. Policies and tools for sustainable water management in the European Union. Environmental Modeling and Software 20(2):93-98.

Lindeijer, E. 2000. Review of land use impact methodologies. Journal of Cleaner Production 8 (4):273-281.

Malczewski, J. 2004. GIS-based land-use suitability analysis: a critical overview. Progress in Planning 62(1):3-65.

Mander, Ü., H. Wiggering, and K. Helming, editors. 2007. Multifunctional land use - meeting future demands for landscape goods and services. Editorial:1-14. Springer, Berlin, Germany.

Matthies, M., C. Guipponi, and B. Ostendorf. 2007. Environmental decision support systems: current issues, methods and tools. Environmental Modeling and Software 22(2):123-127.

Mendoza, A. G., and R. Prabhu. 2005. Combining participatory modeling and multi-criteria analysis for community-based forest management. Forest Ecology and Management 207(1-2):145-156.

Miller, M. M. 1993. Enhancing regional analysis with the Delphi method. Review of Regional Studies 23(2):191-212.

Moreno, N., Wang, F., and D. J. Marceau. 2009. Implementation of a dynamic neighborhood in a land-use vector-based cellular automata model. Computers, Environment and Urban Systems 33 (1):44-54.

Niemelä, J., J. Young, A. Alard, M. Askasibar, K. Henle, R. Johnson, M. Kurttila, T. B. Larsson, S. Matouchi, P. Nowicki, R. Paiva, L. Portoghesil, R. Smulders, A. Stevenson, U. Tartes, and A. Watt. 2005. Identifying managing and monitoring conflicts between forest biodiversity conservation and other human interests in Europe. Forest Policy and Economics 7(6):877-890.

Parker, D. C., A. Hessl, and S. C. Davis. 2008. Complexity, land use modeling, and the human dimension: fundamental challenges for mapping unknown outcome spaces. Geoforum 39(2):789804.

Perez-Soba, M., S. Petit, L. Jones, N. Bertrand, V. Briquel, L. Omodei-Zorini, C. Contini, K. Helming, J. Farrington, M. Tinacci-Mossello, D. Wascher, F. Kienast, and R. de Groot. 2008. Land use functions - a multifunctionality approach to assess the impacts of land use change on land use sustainability. Pages 375-404 in K. Helming, M. Perez-Soba, and P. Tabbush, editors. Sustainability impact assessment of land use changes. Springer, Berlin, Germany.

Repetti, A., M. Soutter, and A. Musy. 2006. Introducing SMURF: a software system for monitoring urban functionalities. Computers, Environment and Urban Systems 30(5):686-707. 
Reynolds, K. M., M. Twery, M. J. Lexer, H. Vacik, D. Ray, G. Shao, and J. G. Borges. 2008. Decision Support Systems in Forest Management. Pages 499-533 in F. Burstein and C. W. Holsapple, editors. Handbook on decision support systems. Springer, Berlin, Germany.

Roetter, R. P., C. T. Hoanh, A. G. Laborte, H. Van Keulen, M. K. Van Ittersum, C. Dreiser, C. A. Van Diepen, and H. H. Van Laar. 2005. Integration of Systems Network (SysNet) tools for regional land use scenario analysis in Asia. Environmental Modeling and Software 20(3):91-307.

Rossing, W. A. H., P. Zander, E. Josien, J. C. J. Groot, B. C. Meyer, and A. Knierim. 2007. Integrative modeling approaches for analysis of impact of multifunctional agriculture: a review for France, Germany and The Netherlands. Agriculture, Ecosystems and Environment 120(1):41-57.

Rounsevell, M. D. A., P. M. Berry, and P. A. Harrison. 2006a. Future environmental change impacts on rural land use and biodiversity: a synthesis of the ACCELERATES project. Environmental Science and Policies 9(2):93-100.

Rounsevell, M. D. A., I. Reginster, M. B. Araújo, T. R. Carter, N. Dendoncker, F. Ewert, J. I. House, S. Kankaanpää, R. Leemans, M. J. Metzger, C. Schmit, P. Smith, and G. Tuck. 2006b. A coherent set of future land use change scenarios for Europe. Agriculture, Ecosystems \& Environment 114(1):57-68.

Sächsisches Ministerium für Umwelt und Landwirtschaft (SMUL). 2003. SMUL SACHSEN (2003): Handlungsempfehlung zur Bewertung und Bilanzierung von Eingriffen im Freistaat Sachsen.

Schmidt-Thomé, P., editor. 2005. The spatial effects and management of natural and technological hazards in Europe. Final report of the European Spatial Planning and Observation Network (ESPON) project 1.3.1, Geological Survey of Finland, Espoo, Finland.

Schmit, C., M. D. A. Rounsevell, and I. La Jeunesse. 2006. The limitations of spatial land use data in environmental analysis. Environmental Science and Policy 9(2):174-188.

Schneeberger, N., M. Burgi, A. M. Hersperger, and K. C. Ewald. 2007. Driving forces and rates of landscape change as a promising combination for landscape change research - an application on the northern fringe of the Swiss Alps. Land Use Policy 24(2):349-361.

Scholles, F. 2001. Delphi. Pages 203-206 in D. Fürst and F. Scholles, editors. Handbuch Theorien + Methoden der Raum- und Umweltplanung (Handbook of theories and methods of spatial and environmental planning) Vol 4. Dortmunder Vertrieb für Bau- und Planungsliteratur, Dortmund, Germany.

Schößer, B., K. Helming, and H. Wiggering. 2009. Assessing land use change impacts - a comparison of the Land Use Function approach with other frameworks. Journal of Land Use Science 5 (2):159-178.

Seffino, L. A., C. B. Medeiros, J. V. Rocha, and B. Yi. 1999. WOODSS - a spatial decision support system based on workflows. Decision Support Systems 27(1):105-123.

Silva, E. A., J. Ahern, and J. Wileden. 2008. Strategies for landscape ecology: an application using cellular automata models. Progress in Planning 70(4):133-177.

Soares-Filho, B. S., G. Coutinho Cerqueira, and C. Lopes Pennachin. 2002. DINAMICA-a stochastic cellular automata model designed to simulate the landscape dynamics in an Amazonian colonization frontier. Ecological Modelling $\mathbf{1 5 4}$ (3):217-235.

Tang, K. X., and N. M. Waters. 2005. The internet, GIS and public participation in transportation planning. Progress in Planning 64(1):7-62.

Tobler, W. 1979. Cellular geography. Pages 379386 in S. Gale and G. Olsson, editors. Pilosophy in geography. Reidel Publisher, Dordrecht, Netherlands.

Turoff, M., and H. Linstone. 1975. The Delphi method: techniques and applications. AddisonWesley, Reading, Massachusetts, USA.

Ulam, S. 1952. Random processes and transformations. Pages 264-275 in Proceedings of the International Congress on Mathematics (2) of American Mathematical Society. Providence, Rhode Island, USA. 
Uran, O., and R. Janssen. 2003. Why are spatial decision support systems not used? Some experiences from the Netherlands. Computers, Environment and Urban Systems 27:511-526.

Uthes, S., K. Fricke, H. König, P. Zander, M. van Ittersum, S. Sieber, K. Helming, A. Piorr and K. Müller. In press. Policy relevance of three integrated assessment tools - a comparison with specific reference to agricultural policies. Ecological Modelling. doi: 10.1016/j.ecolmodel.2009.08.010.

Van Delden, H., P. Luja, and G. Engelen. 2007. Integration of multi-scale dynamic spatial models of socio-economic and physical processes for river basin management. Environmental Modeling and Software 22(2):223-238.

Van Kouwen, F., P. P. Schot, and M. J. Wassen. 2008. A framework for linking advanced simulation models with interactive cognitive maps. Environmental Modelling and Software 23:1133-1144.

Van Paassen A., R. P. Roetter, H. Van Keulen, and C. T. Hoanh. 2007. Can computer models stimulate learning about sustainable land use? Experience with LUPAS in the humid (sub-)tropics of Asia. Agricultural Systems 94(3):874-887.

Verburg, P. H., C. J. E. Schulp, N. Witte, and A. Veldkamp. 2006. Downscaling of land use change scenarios to assess the dynamics of European landscapes. Agriculture, Ecosystems and Environment 114 (1):39-56.

Walker, D. H. 2002. Decision support, learning and rural resource management. Agricultural Systems 73:113-127.

Wiggering, H., C. Dalchow, M. Glemnitz, K. Helming, K. Müller, A. Schulz, U. Stachow, and P.Zander. 2006. Indicators for multifunctional land use - linking socio-economic requirements with landscape potentials. Ecological Indicators 6:238249.

Wiggering, H., K. Mueller, A. Werner, and K. Helming. 2003. The concept of multifunctionality in sustainable land development. Pages 3-18 in K. Helming and H. Wiggering, editors. Sustainable development of multifunctional landscapes. Springer, Berlin, Germany.
Wijewardana, D. 2008. Criteria and indicators for sustainable forest management: the road travelled and the way ahead. Ecological Indicators 8(2):115122.

Wilby, R. L., H. G. Orra, M. Hedger, D. Forrow, and M. Blackmore. 2006. Risks posed by climate change to the delivery of Water Framework Directive objectives in the UK. Environment International 32(8):1043-1055.

Willemen, J. P. M., and L. Kooistra. 2004. Source metadata-catalogue of European spatial datasets. Alterra-rapport 1062 / CGI-report 04-006. Centrum Geo-informatie, ALTERRA - Research Institute for the Green World. Wageningen, Netherlands.

Wilson, D., and R. Purushotaman. 2003. Dreaming with BRICs: the path to 2050. Global Economics Paper No: 99. Goldman Sachs, New York, New York, USA.

White, R., and G. Engelen. 1993. Cellular automata and fractal urban form: a cellular modelling approach to the evolution of urban landuse patterns. Environment and Planning A 25:11751199.

White, R., and G. Engelen. 1994. Urban systems dynamics and cellular automata: Fractal structures between order and chaos. Chaos, Solitons and Fractals 4(4):563-583.

White, R., and G. Engelen. 1997. Cellular automata as the basis of integrated dynamic regional modelling. Environment and Planning B: Planning and Design 24:235-246.

White, R., G. Engelen, and I. Uljee. 1997. The use of constrained celluar automata for high-resolution modelling of urban land-use dynamics. Environment and Planning B: Planning and Design 24:323-343.

White, W., D. R. Lamb, and S. Yun. 2004. Development of an empirically based area-type model. Transportation Research Record: Journal of the Transportation Research Board 1895:25-30.

Wickramasuriya, R. C., A. K. Bregt, H. van Delden, and A. Hagen-Zanker. 2009. The dynamics of shifting cultivation captured in an extended Constrained Cellular Automata land use model. Ecological Modelling 220(18):2302-2309. 
With, K. A., and A. W. King. 1997. The use and misuse of neutral landscape models in ecology. Oikos 79(2):219-229.

Wöbse, H. 2003. Landschaftsästhetik. Ulmer publisher, Stuttgart, Germany.

Yang, Q., X. Li, and X. Shi. 2008. Cellular automata for simulating land use changes based on support vector machines. Computers and Geosciences 34(6):592-602.

Yli-Viikari, A., R. Hietala-Koivu, E. HuuselaVeistola, T. Hyvonen, P. Perala, and E. Turtola. 2007. Evaluating agri-environmental indicators (AEIs)-Use and limitations of international indicators at national level. Ecological Indicators 7 (1):150-163. 